\title{
Sosialisasi anemia dan gizi serta pelatihan pemeriksaan hemoglobin pada guru dan orang tua anak usia sekolah dasar
}

\author{
Mariana*, Emma Novita, Pariyana \\ Departemen Ilmu Kesehatan Masyarakat Fakultas Kedokteran Universitas Sriwijaya \\ E-mail: ma_hanafiah@yahoo.com
}

\begin{abstract}
Abstrak
Anemia merupakan masalah gizi yang mempengaruhi jutaan orang di negara-negara berkembang dan tetap menjadi tantangan besar bagi kesehatan manusia. Prevalensi anemia yang tertinggi terdapat pada kelompok bayi, anak usia sekolah dan anak praremaja. Selain menyebabkan daya tahan tubuh berkurang, kondisi anemia dapat menurunkan kinerja intelektual anak sekolah. Kegiatan pengabdian ini dilaksanakan untuk memberikan edukasi pada guru serta wali siswa SDIT Zain Al Muttaqin dan wali santri Rumah Tahfizh Daaris Alfurqon Kota Palembang. Materi kegiatan berupa edukasi untuk meningkatkan pengetahuan peserta mengenai anemia dan gizi anak usia sekolah dan praktik langsung cara pemeriksaan hemoglobin dengan metode rapid test. Rancangan evaluasi yang digunakan dalam kegiatan ini menggunakan model evaluasi tes tulis dengan 27 pertanyaan mengenai anemia dan gizi pada anak. Berdasarkan distribusi frekuensi pengetahuan peserta sebelum kegiatan, didapatkan 100\% termasuk kategori kurang baik dan Setelah Penyuluhan pengetahuan peserta yang kurang baik menurun menjadi $44,3 \%(p=0.00)$. Setelah mendapatkan penyuluhan, terdapat peningkatan pemahaman mengenai anemia serta gizi pada anak usia sekolah pada guru serta wali siswa SDIT Zain Al Muttaqin dan Rumah Tahfizh Daaris Al Furqon.
\end{abstract}

Kata kunci: Anemia, Gizi, Hemoglobin, Anak

\begin{abstract}
Educating teachers and parents of elementary school aged children about anemia, nutrition and training of hemoglobin level examination. Anemia is a nutritional problem that affects millions of people in developing countries and remains a major challenge to human health. Anemia prevalence in the group of infants, school age children and prepubescent children. In addition to reducing the immune system, anemia can reduce the intellectual performance of school children. This community service activity was carried out to provide education to the teachers and parents of SDIT Zain Al Muttaqin and Rumah Tahfizh Daaris Alfurqon students Palembang. Counseling was carried out to increase participants' knowledge about anemia and nutrition of school age children and direct practice of hemoglobin examination using the rapid test method. The evaluation design used in this activity used a written test evaluation model with 27 questions about anemia and nutrition in children. Based on the frequency distribution of participants' knowledge before the activity, it was found that $100 \%$ was in the poor category and after counseling the number decreased to $44.3 \%$ ( $p=$ 0.00). After receiving counseling, increasing understanding of anemia and nutrition in school-age children in teachers and parents of SDIT Zain Al Muttaqin students and the Tahfizh Daaris Al Furqon House.
\end{abstract}

Keywords: Anemia, Nutrition, Hemoglobin, Children 


\section{PENDAHULUAN}

Masalah kesehatan triple burden di Indonesia masih menjadi tantangan besar bagi Indonesia. Masih adanya penyakit infeksi, peningkatan penyakit tidak menular (PTM) dan penyakitpenyakit yang seharusnya sudah teratasi muncul kembali. Pada era 1990, penyakit menular seperti infeksi saluran napas akut, tuberkulosis dan diare merupakan penyakit terbanyak dalam pelayanan kesehatan. Namun perubahan gaya hidup masyarakat menjadi salah satu penyebab terjadinya pergeseran pola penyakit (transisi epidemiologi). Hasil riset Kesehatan dasar (Riskesdas) 2018, PTM seperti stroke, penyakit jantung koroner (PJK), kanker dan diabetes mengalami peningkatan. ${ }^{1}$ Secara umum, pasien dengan PTM ini bisa disertai dengan anemia. Beberapa penyakit tidak menular yang dapat disertai dengan anemia adalah penyakit jantung stroke diabetes melitus ginjal dan kanker. ${ }^{2}$

Anemia merupakan masalah gizi yang mempengaruhi jutaan orang di negaranegara berkembang dan tetap menjadi tantangan besar bagi kesehatan manusia. Prevalensi Anemia defisiensi besi tinggi pada bayi, hal yang sama juga dijumpai pada anak usia sekolah dan anak praremaja. Angka kejadian Anemia pada anak usia sekolah (5-8 tahun) sekitar 5,5\%, anak perempuan 2,6\% dan gadis remaja yang hamil 26\%. Di Amerika serikat sekitar 6\% anak berusia 1-2 tahun diketahui kekurangan besi, 3 \% menderita anemia. Lebih kurang 9\% gadis remaja di Amerika serikat kekurangan besi dan 2\% menderita anemia, sedangkan pada anak laki-laki sekitar 50\% cadangan besinya berkurang saat pubertas. ${ }^{3}$ Data World Health Organization 2006 dalam Worldwide Prevalence of Anemia menunjukkan bahwa total keseluruhan penduduk dunia yang menderita anemia sebanyak 1,62 miliar orang. ${ }^{4}$ Berdasarkan data Riskesdas tahun 2018, prevalensi anemia di Indonesia sebesar $32 \%{ }^{1}$

Anak usia sekolah adalah investasi bangsa. Upaya peningkatan kualitas sumber daya manusia harus dilakukan sejak dini, secara sistematis dan berkesinambungan. Kualitas bangsa di masa depan ditentukan oleh kualitas anak-anak saat ini. Usia anak sekolah dasar di Indonesia lazimnya 7-12 tahun, sedangkan WHO menyebutkan bahwa 
anak sekolah dasar adalah anak yang berusia antara 7-15 tahun. Kelompok ini rentan terhadap empat masalah gizi di Indonesia. Masalah gizi di Indonesia yang muncul sebagai akibat kebiasaan makan yang salah pada anak usia sekolah adalah Kekurangan Vitamin A (KVA), Gangguan Akibat Kekurangan Yodium (GAKY), Kekurangan Energi Protein (KEP) dan Anemia. ${ }^{5}$ Penyebab anemia gizi besi pada anak sekolah umumnya disebabkan karena kekurangan asupan zat gizi khususnya besi dan zat-zat gizi lain yang membantu penyerapan dan metabolisme besi.

Tujuan pembangunan kesehatan masyarakat di Indonesia pada hakekatnya untuk meningkatkan angka harapan hidup, meningkatkan kualitas sumber daya manusia serta kualitas kehidupan guna meningkatkan kesejahteraan keluarga agar dapat mewujudkan derajat kesehatan masyarakat yang optimal. Kesehatan merupakan salah satu kebutuhan dasar manusia, sehingga perlu senantiasa diusahakan agar setiap penduduk makin menyadari pentingnya kesehatan bagi dirinya sendiri dan lingkungannya, serta makin mampu untuk berperilaku hidup sehat. Dalam rangka mendukung pemerintah telah melakukan langkah nyata untuk meningkatkan sistem kesehatan nasional yang menjadi langkah indikator pencapaian tujuan pembangunan Sustainable Development Goals. Kurangnya pemahaman masyarakat terhadap anemia pada anak menjadi satu permasalahan dalam peningkatan derajat kesehatan masyarakat khususnya pada anak sekolah.

Berdasarkan survei pendahuluan di SDIT Zain Al Muttaqin serta Rumah Tahfizh Daaris Al Furqon, diketahui bahwa daerah Kertapati merupakan wilayah padat penduduk, disekeliling sekolah banyak terdapat warung-warung yang aktif di kelola oleh warga setempat yang menjual berbagai makanan mulai dari makanan yang mengandung karbohidrat sampai makanan ringan yang mengandung zat pengawet serta perwarna. Siswa mempunyai prestasi belajar yang cukup baik (72\%), akan tetapi status gizi berdasarkan IMT/U siswa disekolah tersebut yaitu gizi kurang 26\% dan gizi lebih 16\%. Hasil wawancara awal dengan beberapa guru di SDIT Zain Al Muttaqin dan para Ustadz 
di Rumah Tahfizh Daaris Al Furqon menunjukkan bahwa hampir 80\% siswa mengkonsumsi makanan cepat saji seperti mie goreng, makanan ringan serta jajanan yang mengandung bahan pengawet serta pewarna. Pemberian vitamin A, imunisasi serta penyuluhan tentang kesehatan gigi dan mulut sudah dilaksanakan oleh petugas puskesmas namun penyuluhan tentang anemia dan kebutuhan gizi pada anak belum pernah dilakukan kepada guru maupun orangtua serta siswa itu sendiri oleh pihak petugas kesehatan disekitar wilayah sekolah. Oleh karena itu, perlu adanya sosialisasi untuk peningkatan pengetahuan dan pemahaman masyarakat tentang anemia agar kesadaran tentang bahaya anemia pada anak dapat menjadi motivasi dalam melakukan skrining atau deteksi dini terjadinya anemia dengan melakukan pemeriksaan kadar hemoglobin secara mandiri dan meningkatkan upaya untuk pencegahan dan penanganan anemia pada anak di masyarakat.

Upaya pemberdayaan masyarakat merupakan salah satu upaya yang dapat digunakan sebagai strategi promosi kesehatan baik dalam level primer, sekunder maupun tersier sesuai dengan piagam ottawa carter (Kemenkes, 2017). Pemberdayaan masyarakat ini termasuk dalam Pilar Paradigma Sehat yang dilakukan dengan penguatan promotif, preventif untuk mewujudkan Indonesia Sehat. Dalam kaitannya dengan upaya tersebut, maka perlu dilakukan pelatihan dan pemeriksaan hemoglobin dengan metode Rapid Diagnostic Test secara mandiri oleh tim pengabdian masyarakat FK Unsri terhadap guru dan orangtua.

\section{TINJAUAN PUSTAKA}

Anemia didefinisikan sebagai konsentrasi hemoglobin $(\mathrm{Hb})$ yang rendah dalam darah, yaitu $<11 \mathrm{~g} / \mathrm{dL}$ untuk usia di bawah 4 tahun dan $<11,5 \mathrm{~g} / \mathrm{dL}$ untuk anak di atas 4 tahun. ${ }^{6}$ Penyebab dari anemia gizi adalah kekurangan zat gizi yang berperan dalam pembentukan hemoglobin, baik karena kekurangan konsumsi atau karena gangguan absorpsi. Zat gizi yang terkait adalah besi, protein, piridoksin (vitamin B6) yang berperan sebagai katalisator dalam sintesis hem di dalam molekul hemoglobin, vitamin $C$ yang 
mempengaruhi absorpsi dan pelepasan besi dari transferin ke dalam jaringan tubuh, dan stabilitas membran sel darah merah. Selain itu, anemia gizi juga bisa dipengaruhi oleh zat penghambat penyerapan zat gizi seperti kopi dan teh. ${ }^{7}$

Kekurangan asupan zat besi dapat mengakibatkan rendahnya kadar hemoglobin dalam darah, sehingga oksigen yang dibutuhkan oleh tubuh dan otak menjadi berkurang yang akan berakibat timbulnya perubahan metabolisme di dalam otak. Perubahan metabolisme dalam otak dapat mempengaruhi perubahan jumlah dan fungsi sel di dalam otak, sehingga otak akan mengalami perubahan fungsi normal. Berubahnya fungsi normal otak akan berpengaruh terhadap perkembangan kecerdasan anak dan pencapaian prestasi belajar anak di sekolah. Menurunnya prestasi belajar pada anak sekolah karena mengalami kesulitan berkonsentrasi. Dampak negatif lain yang ditimbulkan oleh anemia defisiensi besi adalah daya tahan tubuh berkurang sehingga menyebabkan tubuh mudah terserang penyakit, serta kemampuan kinerja intelektual juga menurun. ${ }^{4}$

Anemia defisiensi besi pada anak usia sekolah dasar saat ini menjadi masalah gizi yang serius di Indonesia. Anemia defisiensi besi pada anak usia sekolah dasar menjadi masalah kesehatan yang belum terselesaikan karena prevalensinya lebih dari standar nasional yaitu $\geq 20 \%{ }^{8}$ Salah satu strategi agar masyarakat sadar bahaya anemia bagi kesehatan anak adalah pendampingan pemberdayaan dan peningkatan peran masyarakat terhadap upaya kesehatan. Masyarakat diberi bimbingan dalam mengembangkan wadah untuk berperan, dibekali pengetahuan dan keterampilan untuk mengenali masalah di wilayahnya, mengidentifikasi, merumuskan dan menyelesaikan permasalahannya sendiri berdasarkan prioritas dan potensi yang ada. ${ }^{1}$

\section{METODE}

Kegiatan pengabdian dilaksanakan pada hari Sabtu tanggal 02 November 2019 pukul 07.30 sampai dengan pukul 12.00 WIB. Kegiatan ini diikuti oleh 70 peserta, terdiri dari 20 orang pengajar dan staf yayasan serta 50 orang wali siswa SDIT dan santri tahfizh. Sebelum penyuluhan, peserta diminta untuk mengisi kuesioner pretest yang dibagikan oleh 
penyuluh. Kuesioner berisi pertanyaan-pertanyaan mengenai materi yang akan diberikan. Hasil dari evalusi ini berupa skor yang didapatkan dari skor jumlah jawaban benar dibagi total jumlah pertanyaan dikali seratus.

Narasumber dari Tim IKM IKK Fakultas Kedokteran Universitas Sriwijaya. Materi yang diberikan oleh dr. Emma Novita M. Kes. mengenai "Anemia pada Anak", materi dari Mariana SKM. M.Kes mengenai "Makanan Bergizi untuk Anak sekolah" dan materi dari Tim IKM IKK beserta Mahasiswa yaitu tentang “Panduan Pemeriksaan Hamoglobin Metode Rapid Test".

Materi diberikan dengan metode diskusi interaktif. Peserta terlihat antusias mendengarkan materi yang disampaikan oleh narasumber. Sesi tanya jawab dibuka setelah ketiga narasumber selesai menyampaikan materi. Dalam sesi tanya jawab, ada tiga pertanyaan yang diajukan kepada narasumber. Di akhir kegiatan, peserta kembali diberikan kuesioner untuk diisi. Kuesioner ini adalah posttest dari kegiatan penyuluhan. Posttest diberikan untuk mengevaluasi tujuan pencapaian dari penyuluhan. Skor posttest didapat dengan cara yang sama dengan pretest. Skor pretest dan posttest kemudian dibandingkan untuk melihat ada tidaknya peningkatan pengetahuan peserta. Apabila terjadi peningkatan lebih dari $80 \%$ peserta atau pada 56 peserta, maka kegiatan penyuluhan dianggap berhasil meningkatkan pengetahuan masyarakat.

Rancangan evaluasi yang digunakan dalam kegiatan ini menggunakan model evaluasi tes tertulis. Instrumen tes yang digunakan adalah kuisioner dengan 2 opsi pilihan (benar atau salah) dengan jumlah soal sebanyak 27 butir. Teknik penilaian skor terhadap soal dilaksanakan dengan konversi menggunakan metode skala nilai dengan rentang nilai 1 dan 0. Dimana telah ditentukan kunci jawaban sebelumnya, sehingga skor diberikan dengan cara membuat urutan: untuk opsi jawab benar skor 1, untuk opsi jawaban salah skor 0. Untuk menetukan batas kriteria selanjutnya dilakukan teknik perhitungan sebagai berikut:

$$
\mathrm{N}=(\text { Skor perolehan total } \times 100 \%) \text { /skor maksimal total }
$$

Ket: $\mathrm{N}=$ nilai persentase kemampuan menjawab soal 


\section{HASIL DAN PEMBAHASAN}

Berdasarkan distribusi usia, rentang usia terbanyak pada kelompok 30-34 tahun yaitu sebesar 34,3\%. Berdasarkan distribusi frekuensi berdasarkan jenis kelamin, didapatkan bahwa jenis kelamin perempuan sebanyak 88,6\% lebih banyak dibandingkan dengan jenis kelamin laki-laki sebanyak 11,4\%. Peserta paling banyak berpendidikan SMA (55,7\%), berpendidikan SMP dan D3/D4/S1 masing-masing sebanyak 18,6\% dan paling sedikit tidak sekolah yaitu 1,4\%. Pekerjaan yang paling banyak ditemukan yaitu sebagai IRT (48,6\%), diikuti sebagai karyawan swasta sebanyak 22,9\%.

Tabel 1. Distribusi Frekuensi Pengetahuan Peserta Sebelum dan Setelah Penyuluhan

\begin{tabular}{lcc}
\hline Pengetahuan & Jumlah (n) & Persen (\%) \\
\hline Sebelum penyuluhan & & \\
- Kurang baik & 70 & 100,0 \\
- Cukup & 0 & 0,0 \\
- Baik & 0 & 0,0 \\
\hline Setelah penyuluhan & & \\
- Kurang baik & 31 & 44,3 \\
- Cukup & 26 & 37,1 \\
- Baik & 13 & 18,6 \\
\hline
\end{tabular}

Ket: Kategori pengetahuan dikategorikan menjadi:

Kurang $<65 \%$ jawaban benar

Cukup 65-8\% jawaban benar

Baik $>80 \%$ jawaban benar

Berdasarkan Tabel 1, pengetahuan peserta sebelum kegiatan termasuk kategori kurang baik dan setelah penyuluhan pengetahuan peserta yang kurang baik menurun menjadi 44,3\% yang artinya ada peningkatan pengetahuan peserta sebelum dan setelah dilakukan penyuluhan sebesar 55,7\%. Total peserta yang memiliki pengetahuan baik setelah dilakukan penyuluhan adalah 57 peserta. 
Tabel 2. Persentase pengetahuan peserta sebelum dan setelah Penyuluhan

\begin{tabular}{lll}
\hline Pengetahuan $(\%)$ & Rerata \pm SD & Min-Maks \\
\hline Pretest & $34,44 \pm 6,22$ & $25,93-44,44$ \\
Posttest & $65,82 \pm 13,13$ & $40,74-92,59$ \\
\hline
\end{tabular}

Jumlah masing-masing pertanyaan pengetahuan 27 soal dengan jawaban benar dan salah. Jika benar mendapat nilai 1, jika salah nilai 0. Pengetahuan dipersentasekan dengan rumus (jumlah jawaban benar/dengan total soal)*100. Rerata pengetahuan setelah diberikan penyuluhan mengalami peningkatan (Tabel 2).

Tabel 3. Perbedaan pengetahuan sebelum dan sesudah penyuluhan

\begin{tabular}{lccc}
\hline Pengetahuan & Median & Min - Mak & $p$ value \\
\hline Sebelum penyuluhan & 33,33 & $25,93-44,44$ & \\
Setelah penyuluhan & 68,51 & $40,74-92,59$ & 0,000 \\
\hline
\end{tabular}

Antusiasme orangtua sangat baik ketika pemberian edukasi. Hal ini tergambar dari terciptanya komunikasi dua arah antara narasumber dan peserta kegiatan dilanjutkan dengan posttest anemia pada anak. Berdasarkan analisis SPSS menggunakan uji Shaphiro Wilk (data berdistribusi normal), terdapat peningkatan pengetahuan orangtua mengenai anemia pada anak antara hasil tes kelompok pretest dan posttest (Tabel 5). Sesuai penelitian sebelumnya, penyuluhan menjadi metode yang efektif dalam meningkatkan pengetahuan kesehatan masyarakat. ${ }^{9,10}$

\section{SIMPULAN}

Setelah mendapatkan penyuluhan, terdapat peningkatan pemahaman mengenai anemia serta gizi pada anak usia sekolah pada guru staf serta wali siswa SDIT dan Wali Santri Rumah Tahfizh Daaris Alfurqon. Setelah mengikuti kegiatan penyuluhan ini, para peserta 
diharapkan mampu mengaplikasikan pemeriksaan hemoglobin terhadap peserta didik. Wali siswa maupun wali santri diharapkan dapat memberikan makanan bergizi kepada keluarga khususnya anaknya yang masih diusia sekolah serta menyebarluaskan pengetahuan yang didapat dari kegiatan ini kepada keluarga dan masyarakat sekitar.

Perlu diadakan kegiatan serupa di institusi pendidikan baik di kota Palembang ataupun di daerah lainnya yang belum memiliki kesempatan melakukan kegiatan ini, agar pengetahuan mengenai anemia serta gizi pada anak usia sekolah dapat tersebar lebih luas.

\section{Ucapan Terima Kasih}

Terima kasih yang sebesar-besarnya penulis ucapkan kepada Rektor Universitas Sriwijaya, Dekan Fakultas Kedokteran Universitas Sriwijaya, Ketua Pusat Pelayanan dan Pengembangan Lembaga Penelitian dan Pengabdian (PPP-LPPM) UNSRI, Kepala Sekolah SDIT Zain Al Muttaqin, Kepala Rumah Tahfizh Daaris Al Furqon Palembang dan semua pihak yang telah membantu dan memfasilitasi dalam pelaksanaan kegiatan pengabdian masyarakat ini sehingga proses pelaksanaan dapat berjalan dengan baik.

\section{Referensi}

1. Ministry of Health Republic of Indonesia. Basic Health Research Report of Indonesia Year 2018 (Laporan Nasional Riskesdas 2018).; 2018.

2. Drakos SG, MI A-N, KG M, JN. N. Anemia in chronic heart failure. Congest Hear Fail. 2009;15:87-92.

3. Ozdemir N. Iron deficiency anemia from diagnosis to treatment in children. Türk Pediatr Arşivi. 2015;50(1):11-19. doi:doi:10.5152/tpa.2015.2337

4. McLean E, Cogswell M, Egli I, Wojdyla D, De Benoist B. Worldwide prevalence of anaemia, WHO Vitamin and Mineral Nutrition Information System, 1993-2005. Public Health Nutr. 2009;12(4):444-454. doi:10.1017/S1368980008002401

5. Moehji S. Ilmu Gizi 2 Penanggulangan Gizi Buruk. Jakarta: Papas Sinar Sinanti; 2003.

6. Moshe G, Amitai Y, Korchia G, et al. Anemia and iron deficiency in children: Association with red meat and poultry consumption. J Pediatr Gastroenterol Nutr. 2013;57(6):722-727. doi:10.1097/MPG.0b013e3182a80c42

7. Arisman. Gizi Dalam Daur Kehidupan. Jakarta: EGC; 2010.

8. Judarwanto W. Perilaku Makan Anak Sekolah. Jakarta: Direktorat Bina Gizi Kementerian Kesehatan Republik Indonesia; 2011. 
9. Wijayanti RA, Nuraini N, Deharja A. Efektivitas penyuluhan perilaku hidup bersih dan sehat (PHBS) dalam meningkatkan pengetahuan siswa di SMP Islam Mahfilud Duror Jelbuk. J Ilm Inov. 2017;16(3). doi:10.25047/jii.v16i3.312

10. Zulaekah S, Widajanti L, Korespondensi A, et al. Pengetahuan gizi dan kadar hemoglobin anak sekolah dasar penderita anemia setelah mendapatkan suplementasi besi dan pendidikan gizi. Kesmas J Kesehat Masy Nas (National Public Heal Journal). 2010;5(1):36-41. doi:10.21109/KESMAS.V5I1.160 